\title{
Burdur İli Karbon Ayak İzinin Belirlenmesi
}

\section{Determination of Burdur Province Carbon Footprint}

\author{
İbrahim Kırbaş ${ }^{1}$, Tolga Kocakulak ${ }^{1^{*}}$ \\ ${ }^{1}$ Burdur Mehmet Akif Ersoy Üniversitesi, Teknik Bilimler MYO, Burdur, TÜRKIYE
}

Sorumlu Yazar / Corresponding Author*: tkocakulak@mehmetakif.edu.tr

\author{
Geliş Tarihi / Received: 30.04 .2021 \\ Kabul Tarihi / Accepted: 30.07.2021 \\ Araștırma Makalesi/Research Article \\ Atıfsekli/How to cite:KIRBAȘ, I.,KOCAKULAK,T.(2022). Burdur İli Karbon Ayak İzinin Belirlenmesi.DEUFMD, 24(70), 317-327.
}

\section{$\ddot{0} \mathbf{z}$}

Bu çalışmada, Burdur ilinin tüm ilçelerini kapsayan, karbon ayak izi değeri belirlenmiștir. Karbon ayak izinin belirlenmesinde kapsam 1, kapsam 2 ve kapsam 3 faktörleri hesaba dahil edilmiştir. Kapsam 1'de konut, serbest tüketici ve ulaşımdan kaynaklı salınımlar incelenmiștir. Kapsam 2'de konut, sanayi, ticarethane ve kurumlara ait elektrik tüketiminden dolayı meydana gelen salınımlar dahil edilmiștir. Kapsam 3'te ise çöp ișleme tesislerinde meydana gelen salınımlara yer verilmiștir. Kapsam 1 içerisinde bulunan konut faktörü, kömür ve doğalgaz kullanımına bağlı, ulaşım faktörü ise hem araç tiplerine hem de yakıt cinslerine bağlı olarak değerlendirmesi yapılmıștır. Burdur ili $\mathrm{CO}_{2}$ emisyon salınımı kapsam 1 ile 723,54, kapsam 2 ile 364,29 ve kapsam 3 ile 9,76 ve toplamda ise $1.097,60$ bin ton/yll olarak belirlenmiştir. Kapsam 1'de gerçekleşen $\mathrm{CO}_{2}$ salınımının \%58,14'ü konut, \%32,41'i ulașım, \%9,46'sı serbest tüketiciler tarafından gerçekleștirildiği görülmüștür. Ulaşımda, \%69,33'lük oranla en çok emisyon salınımı dizel taşıtlar tarafından gerçekleşirken, $\% 16,41$ 'lik oranla benzinli, \%14,19 oranla LPG'li ve \%0,17'lik oranla ise elektrikli taşıtların kapsadığı görülmüştür. Kapsam 2 kategorisinde konutun 75,57, sanayinin 182,45, ticarethane ve kurumların 822,83, aydınlatmanın 17,12 ve tarımsal sulamanın 6,28 bin ton/yll $\mathrm{CO}_{2}$ emisyonu salınımı gerçekleştirdiği sonucuna ulaşılmıștır. Burdur iline ait ağaç sayısı ile yıllık emilen $\mathrm{CO}_{2}$ emisyon miktarı 559,16 bin ton/yll olarak belirlenmiştir. Belirlenen kapsamlar doğrultusunda Burdur ilinde yıllık 538,44 bin ton $\mathrm{CO}_{2}$ emisyon açı̆̆ı vermektedir. Bu açı̆̆ın giderilmesi için yaklaşık 45 milyar ağaç yetiştirilmesi gerekmektedir.

Anahtar Kelimeler: Karbon Ayak İzi, Sera Gazı, İklim Değișikliği, Küresel Isınma, Burdur

\section{Abstract}

In this study, the carbon footprint value covering all districts of Burdur province was determined. Scope 1, scope 2 and scope 3 factors were taken into account in determining the carbon footprint. In Scope 1, emissions originating from housing, free consumer and transportation have been examined. In Scope 2, emissions due to electricity consumption of houses, industry, businesses and institutions are included. Scope 3 includes emissions that occur in garbage processing facilities. The housing factor included in Scope 1 is based on the use of coal and natural gas, while the transportation factor has been evaluated based on both vehicle types and fuel types. The $\mathrm{CO}_{2}$ emission in Burdur is determined as 723.54 with scope 1, 364.29 with scope 2, 9.76 with scope 3 and 1097.60 thousand tons / year in total. 58,14\% of the $\mathrm{CO}_{2}$ emission realized in Scope 1 was realized by housing, $32.41 \%$ by transportation, $9.46 \%$ by free consumers. In transportation, while diesel vehicles emit the most emission with a rate of $69.33 \%$, it was observed that gasoline with 
$16.41 \%$, LPG with $14.19 \%$ and electric vehicles with a rate of $0.17 \%$. In the Scope 2 category, it has been concluded that houses emit 75.57 tons of $\mathrm{CO}_{2}, 182.45$ to industry, 822.83 to businesses and institutions, 17.12 to lighting, and 6.28 thousand tons / year to agricultural irrigation. The number of trees belonging to the province of Burdur and the amount of $\mathrm{CO}_{2}$ emission annually have been determined as 559.16 thousand tons / year. In line with the determined scopes, Burdur has an annual deficit of 538.44 thousand tons of $\mathrm{CO}_{2}$ emission. In order to eliminate this deficit, it is necessary to grow abouth 45 million trees.

Keywords: Carbon Footprint, Greenhouse Gas, Climate Change, Global Warming, Burdur

\section{Giriş}

Yeryüzündeki canlılar yașamlarının devamı için belirli kaynakları kullanmak zorundadır. Kaynakların kullanılma oranı ve oluşan tahribatın belirlenmesi için kullanılan ve başvurulan yöntemler bütünü ise ekolojik ayak izi olarak tanımlanmaktadır [1]. Daha kısa şekilde tanımlayacak olursak Ekolojik Ayak İzi muhasebesi, Dünya'nın biyolojik kapasitesinin arz ve talebini ölçmektedir [2]. Yașamsal faaliyetlerimizi doğal kaynakların kendini yenileme süreleri içerisinde gerçekleştirip gerçekleștirmediğimizi belirlemek istiyorsak; Ekolojik Ayak İzini yaşamsal faaliyetimiz süresinde üretebileceğimiz doğal kaynak miktarıyla (biyolojik kapasite/biyo-kapasite) karşılaștırarak görebiliriz [3]. Ayrıca kullanılan kaynakları, kullanılabilir kaynaklar ile karşılaştırmak suretiyle elde edilen ekolojik ayak izi sayesinde sürdürülebilirliği ne kadar sağlandığını da görmemiz mümkündür.

2012 yılında hazırlanan Türkiye'nin ekolojik ayak izi raporuna göre, ekolojik ayak izinin belirlenmesine etki eden 6 alt başlık olduğu bildirilmektedir. Bunlar; Karbon ayak izi (\%46), Tarım arazisi ayak izi (\%35), Orman ayak izi (\%11), Yapılandırılmıș alan ayak izi (\%3), Otlak ayak izi (\%3) ve Balıkçılık sahası ayak izi (\%2) dir [3]. Ekolojik ayak izinin alt başlıklarından biri ve en büyük paya sahip olan karbon ayak izi aynı zamanda en hızlı büyüyen bir bileșenidir $[4,5]$. Karbon ayak izi, canlıların faaliyetleri sonucu oluşan sera gazı miktarının karbondioksit $\left(\mathrm{CO}_{2}\right)$ eşdeğeri olarak ton $\left(\mathrm{tCO}_{2}\right)$ cinsinden belirlenmesidir [6,7].

Karbon ayak izi doğrudan (birincil) ve dolaylı (ikincil) olmak üzere ikiye ayrılır. Birincil ayak izi ulaşım, barınma ve katı atıklardan oluşan $\mathrm{CO}_{2}$ emisyonlarını kapsamaktadır. İkincil ayak izi ise kullandığımız ürünlerin üretiminden tașınmasına, kullanımından doğada yok olmasına kadar geçen süre zarfında meydana gelen $\mathrm{CO}_{2}$ emisyonlarını kapsar. İkincil ayak izi kısaca ürünün imalatından başlayıp doğada yok olma süresince oluşan $\mathrm{CO}_{2}$ emisyonlarının toplamıdır [8].

Karbon ayak izinin belirlenmesi için yapılacak çalışmalar bireysel, kurumsal, bölgesel, organizasyon vb. odaklı olabilmektedir. Genellikle yıl bazında olmak üzere belli bir zaman dilimi için yapılabilir $[9,10]$. Yakıtların kullanımı sonrası oluşan $\mathrm{CO}_{2}$ miktarının belirlenmesinde Hükümetler Arası İklim Değişikliği Paneli (IPCC) yönergeleri ve standartları kullanılmaktadır. $\mathrm{Bu} \mathrm{CO}_{2}$ miktarının belirlenmesi için Tier 1 , Tier 2 ve Tier 3 olmak üzere 3 yöntem bulunmaktadır. Tier 1 yönteminde yakıtların veya enerjilerin kullanımına bağlı belirlenmiş emisyon faktörlerinden faydalanılmaktadır. Tier 2 yönteminde, yakıtların yanma teknolojisi dikkate alınarak, belirlenmiş ülke veya bölge için oluşturulan dönüşüm faktörleri kullanılmaktadır. Tier 2 yönteminde, Tier 1 yöntemine göre daha ayrıntılı bilgiler kullanması gerekmektedir. Tier 3 yönteminde ise yanma teknolojisi, çalışma koşulları, kontrol teknolojisi, bakım kalitesi ve yanma ekipmanının yaşı gibi bilgiler kullanılmaktadır $[11,12,13]$.

Sunuta vd., yaptıkları çalıșmada Dan Sai Municipality şehrine ait karbon ayak izi değerlerini hesaplamıșlardır. Hesaplama yönteminde, şehrin bulunduğu ülke ve şehre ait kurum ve kuruluşlardan bilgi toplayarak analizini yapmışlardır. Analiz içeriğini kapsam 1, kapsam 2 ve kapsam 3 olarak üç grupta incelemișlerdir. Çalıșma sonucunda Dan Sai şehrinin karbon ayak izinin toplam 8.528,04 $\mathrm{tCO}_{2}$, kapsam $15.524 \mathrm{tCO}_{2}$, kapsam 22.164 ve kapsam 3'ün ise $1.140 \mathrm{tCO}_{2}$ olduğu sonucunu elde etmişlerdir [14]. Argun vd., çalışmalarında Konya ili Selçuklu ilçesine ait karbon ayak izinin belirlenmesini ele almışlardır. Karbon ayak 


\section{DEÜ FMD 24(70), 317-327, 2022}

izinin hesaplanması için kullanılan metotta IPCC tarafından önerilen ve Tier yaklaşımlarıyla belirlenmiş olan metodoloji kullanılmıştır. Çalışma sonucunda Selçuklu ilçesinin karbon ayak izi 940 bin ton $\mathrm{CO}_{2}$ olarak hesaplanmıștır. Çalışmada sanayi faktörü ihmal edilmiş olup, toplam karbon ayak izinin \%56'lı oranını barınma, \%41'lik oranını ulaşım amaçlı meydana geldiğini saptamışlardır [15]. Kocaman, yaptığı çalışmada Karabük ilinin karbon emisyon miktarını hesaplamıștır. Hesaplama sürecinde kullanılan veriler, sanayi, barınma ve ulaşım kullanımı ile kaynaklı olarak sınıflandırılmıştır. Çalışmada verilerin analizinde, IPCC'nin önermiş olduğu Tier 1 hesaplama metodunu kullanmıștır. Elde edilen sonuçlara göre Karabük ilinin 2017 karbon emisyon değeri 2,8 milyon ton, 2018 yllında 2,3 milyon ton ve 2019 yllında ise 7 milyon ton $\mathrm{CO}_{2}$ olarak belirlemiștir. Salınımı yaplan bu değerlerin, 1,2 milyon ton $\mathrm{CO}_{2}$ 'nin ilde bulunan ağaçlar tarafından emiliminin sağlandığı sonucuna ulașmıștır [16]. Kumaș vd., yaptıkları çalışmada Burdur Mehmet Akif Ersoy Üniversitesi Bucak Sağlık Yüksekokulunun yıllık karbon ayak izi miktarını belirlemişlerdir. Miktarın belirlenmesinde, Yüksekokulda kullanılan elektrik enerjisi tüketimi, öğrenci ve personelin ulaşımı, ısınma gibi temel faktörler ele alınmıștır. Yüksekokulun toplam karbon ayak izi miktarı yıllık, $214.503 \mathrm{~kg}$ olarak tespit edilmiştir. $\mathrm{Bu}$ çalıșmada, karbon ayak izi değerine en çok etki eden faktör doğalgaz tüketimi olduğu tespit edilmiştir [17]. Kumaş vd., Muğla havalimanından yapılan uçușlarda, uçak tipi ve sayısına bağlı olarak karbon ayak izi değerini hesaplamışlardır. Hesaplama metodu olarak IPCC'nin önerdiği Tier hesaplama yöntemini kullanmışlardır. Çalıșma sonucunda ele alınan havalimanının karbon ayak izi miktarı ylllık, 93.410,75 $\mathrm{tCO}_{2}$ olarak belirlenmiștir [18]. Bıyık vd., Isparta ilinin ulaștırma sektöründen kaynaklanan, karayolu karbon ayak izi değerini hesaplamıșlardır. $\mathrm{Bu}$ çalıșmada IPCC'nin önerdiği Tier yaklaşım metodu kullanılmıștır. 2010 ile 2016 yılları arasında hesaplanan karbon ayak izi miktarında \%43'lük bir artış olduğu sonucuna ulașmıșlardır [19]. Literatürde bulunan çalıșmalarda IPCC'nin önermiș olduğu Tier metodu ile hesaplamaların gerçekleştiği ve başarılı sonuca ulaşıldı̆̆ ek olarak karbon ayak izinin hesaplanmasında, Burdur ilini kapsayan bir örneklemin yer almadığı görülmüştür.
$\mathrm{Bu}$ çalışmada, Burdur ilinin tüm ilçelerini kapsayan, karbon ayak izi değeri belirlenmiștir. Karbon ayak izinin belirlenmesinde kapsam 1, kapsam 2 ve kapsam 3 faktörleri hesaba dahil edilmiştir. Kapsam 1'de konut, sanayi, ticarethane-kurumlar ve ulaşımdan kaynaklı salınımlar incelenmiştir. Kapsam 2'de konut, sanayi, ticarethane ve kurumlara ait elektrik tüketiminden dolayı meydana gelen salınımlar dahil edilmiştir. Kapsam 3'te ise çöp işleme tesislerinde meydana gelen salınımlara yer verilmiștir. Kapsam 1 içerisinde bulunan konut faktörü, kömür ve doğalgaz kullanımına bağll, ulaşım faktörü ise hem araç tiplerine hem de yakıt cinslerine bağlı olarak değerlendirmesi yapılmıştır. Burdur iline ait ağaç sayısı ile yıllık emilen $\mathrm{CO}_{2}$ emisyonunun karbon ayak izine etkisine de yer verilmiștir.

\section{Materyal ve Metot}

Çalışma bölgesi olarak belirlenen Burdur ili karbon ayak izinin belirlenmesinde birincil ayak izi hesaplanacak olup, kapsam 1, kapsam 2 ve kapsam 3 içeriğinde yer alan barınma, ulașım ve katı atıklardan kaynaklı emisyon hesapları yapılmıștır. Ülke ve il bazında bulunan kurum ve kuruluşlardan gerekli veriler toplanıp, uluslararası standartlarda yer alan karbon ayak izi faktörleri kullanımı ile verilerin analizi gerçekleștirilmiştir.

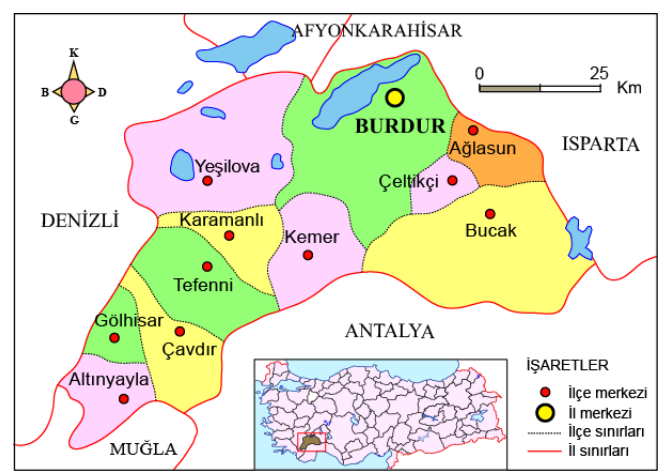

Şekil 1. Burdur ili fiziki haritası

Burdur İli; Merkez ilçeyle birlikte, Ağlasun, Altınyayla, Bucak, Çavdır, Çeltikçi, Gölhisar, Karamanl,, Kemer, Tefenni, Yeșilova olmak üzere; 11 ilçe, 15 belediyeden oluşmaktadır. Belediyeler içinde 127 mahalle ve 193 köy bulunmaktadır. Burdur iline ait fiziki harita Şekil 1'de görülmektedir [20]. Burdur ili toplam nüfusu 267.092, Türkiye nüfus sıralamasında 65. sırada yer almaktadır. Burdur ili 2018 


\section{DEÜ FMD 24(70), 317-327, 2022}

yllında 269.926, 2019 yılında 270.796 ve 2020 yllında ise 267.092 nüfusa sahiptir [21]. Türkiye'nin nüfus yoğunluğu $104 \mathrm{kişi} / \mathrm{km}^{2}$ iken Burdur ili nüfus yoğunluğu $38 \mathrm{kiși} / \mathrm{km}^{2}$ Türkiye'nin yıllık nüfus artış hızı: \%13,5 iken Burdur ilinin yıllık nüfus artış hızı \% 12,8 ile 48. sıradadır. Yüzölçümü $7.176 \mathrm{~km}^{2}$ ve $950 \mathrm{~m}$ rakımda bulunan bir ildir.

2020 yll itibariyle Burdur ili 93.815 konut ile Türkiye toplam konut sayısı (24.604.086) içinde $\% 0,38$ lik bir paya sahiptir. Konutların kullanım şekillerine göre dağılımı ise \%63,2'lik kısmında çekirdek aileler, \%24,2'lik kısmında tek kiși ve $\% 10,4^{\prime}$ lük kısmında ise geniş (kalabalık) hanehalkı kullanımındadır [21].

Burdur ili doğalgaz dağıtım ve altyapı hizmetleri, Torosgaz Isparta Burdur Doğalgaz Dağıtım A.Ş. şirketinin 28 Haziran 2006 tarihinde Enerji Piyasası Düzenleme Kurumundan dağıtım lisansını almasıyla başlamıştır. İlk olarak Merkez ilçede sanayi ve konutlarda doğalgaz kullanımına başlanmıştır. Daha sonra 2011 yılında Bucak ilçesinde ve 2019 yılında Gölhisar ilçesinde doğalgaz kullanımına bașlanmıștır. 2020 yılına ait Burdur Merkez ve diğer iki ilçedeki abone sayısı ile doğalgaz kullanım miktarına ait veriler Tablo 1 'de görülmektedir [22,23]. Ayrıca toptan satış lisansı ile Aygaz ve İpragaz şirketleri, sıkıştırılmış doğalgaz lisansı ile Naturelgaz şirketi, ithalat lisansı ile de Boru Hataları ile Petrol Taşıma Anonim Şirketi (BOTAŞ) bölgedeki doğalgaz arzına cevap vermektedir. Tüm bu lisanslı şirketlerin Evsel tüketici haricindeki tüm tüketiciler serbest tüketici statüsünde değerlendirilmiştir.

Tablo 1. Burdur ili 2020 doğalgaz kullanımı ve abone sayısı

\begin{tabular}{lcc}
\hline Burdur & $\begin{array}{c}\text { Abone } \\
\text { Sayısı }\end{array}$ & $\begin{array}{l}\text { Ylllık Doğalgaz } \\
\text { Tüketimi }\left(\mathrm{m}^{3}\right)\end{array}$ \\
\hline Evsel Tüketici & 48.040 & $46.262 .520,00$ \\
Serbest Tüketici & 2.404 & $33.737 .480,00$ \\
\hline
\end{tabular}

Türkiye Elektrik Dağıtım A.Ş (TEDAŞ) tarafindan 21 farklı bölgeye ayrılarak özelleștirilen Türkiye elektrik dağıtım altyapısı günümüzde tamamen özel sektör tarafından işletilmektedir. Bu özelleştirme ile 28 Mayıs 2013 tarihinden itibaren 10. dağıtım bölgesinde faaliyet gösteren Akdeniz Elektrik Dağıtım A.Ș. (AKDENIZ EDAŞ), Antalya, Isparta ve Burdur şehirlerine hizmet vermektedir. CK Enerji Akdeniz Elektrik perakende satış şirketi olarak Enerji Piyasası Düzenleme Kurumu tarafından verilen lisans doğrultusunda ulusal tarifeden perakende elektrik satışı yapmaktadır [24].

Türkiye'de 2019'da 290 milyar 445 milyon 456 bin kilovatsaat (kWh) elektrik tüketilirken, bu rakam 2020'de yüzde 0,14 artarak 290 milyar 856 milyon 21 bin kWh olarak belirlenmiştir. Enerji piyasası Düzenleme Kurulu (EPDK) elektrik piyasası sektör raporuna göre Burdur ilinin elektrik tüketim oranı Türkiye toplam tüketiminin $\% 0,304$ 'ü kadardır. $\mathrm{Bu}$ oran sonucunda Burdur ili elektrik tüketimi 2020 yılı ocak ayında 61.001,68 MWh ve ylllk ise 884.202,303 MWh olarak belirlenmiştir. EPDK raporu doğrultusunda Burdur ili ocak ayı tüketici türü bazında elektrik tüketimine ait son üç yıllık veriler Tablo 2'de görülmektedir [25].

Tablo 2. Faturalanan elektrik tüketiminin tüketici türü bazında dağılımı

\begin{tabular}{lrrr}
\hline \multicolumn{1}{c}{$\begin{array}{c}\text { Tüketici } \\
\text { Türü }\end{array}$} & $\begin{array}{c}\text { 2018 } \\
\text { Ocak } \\
(\mathrm{MWh})\end{array}$ & \multicolumn{1}{c}{$\begin{array}{c}\text { Ocak } \\
\text { Ochh) }\end{array}$} & \multicolumn{1}{c}{$\begin{array}{c}\text { Ocak } \\
\text { Ocakh) } \\
(\mathrm{MWh})\end{array}$} \\
\hline $\begin{array}{l}\text { Aydınlatma } \\
\text { Mesken }\end{array}$ & $2.267,74$ & $2.658,83$ & $2.872,18$ \\
Sanayi & $13.094,94$ & $12.322,69$ & $12.655,39$ \\
Tarımsal & $47.891,58$ & $26.543,68$ & $30.551,59$ \\
Sulama & 489,41 & 574,49 & $1.051,66$ \\
Ticarethane & $16.124,60$ & $14.333,90$ & $13.870,86$ \\
İl Toplam & $79.868,27$ & $56.433,59$ & $61.001,68$ \\
\hline
\end{tabular}

Barınma kaynaklı emisyon hesaplarının yapılabilmesi için elde edilen veriler Tablo 3'te özetlenmiștir. Burdur ili içinde 48.040 konut doğalgaz kullanmaktadır. Geriye kalan 45.775 konut ısınma ihtiyaçlarını kömür ile karșıladığı kabul edilmiştir. Günümüzde sıvı yakıt kullanımı ekonomik olmaması nedeniyle tercih edilmezken bazı kamu binaları dışında kullanımı yoktur. Bu yüzden hesaplamalarda ayrı bir kalem teșkil etmemiștir. Isınmada kullanılan yakıt türü olarak doğalgaz ve kömür kullanımının olduğu kabul edilmiștir. Gürsoy Haksevenler, yapmış oldukları Ümraniye belediyesi karbon ayak izinin belirlenmesi adlı çalışmasında Hane başına olan kömür tüketimini ortalama 1,5 ton olarak almıștır [26]. TSE 825 Binalarda Isı Yalıtım Kuralları standardına göre İstanbul ili Türkiye 2. Isı bölgesinde yer almaktadır. Burdur ise 3. Isı bölgesi illerindendir ve ısınma için daha fazla enerjiye ihtiyaç duyar. Argun vd., 3. Isı bölgesi olan Konya ili Selçuklu ilçesi karbon ayak izinin 


\section{DEÜ FMD 24(70), 317-327, 2022}

belirlenmesi adlı çalıșmalarında hane bașına ortalama kömür kullanımını 2,5 ton olarak hesaplamışlardır [15]. Yakıt dönüşüm faktörleri tablosunda 3 tür kömür için (endüstriyel olarak kullanılan kömür, elektrik dönüşümünde kullanılan kömür ve evsel kullanımdaki kömür) emisyon değeri verilmiştir [27]. Bu sebeple çalışma kapsamında hane başına ortalama kömür tüketimi 2,5 ton ve evsel kömür olarak kullanılacaktır.

Tablo 3. Burdur ili barınma kaynaklı emisyon hesabında kullanılan veriler

\begin{tabular}{ccc}
\hline $\begin{array}{c}\text { Emisyon } \\
\text { Kaynağı }\end{array}$ & $\begin{array}{c}\text { Kullanan } \\
\text { Hane Sayısı }\end{array}$ & $\begin{array}{c}\text { Yıllık Tüketim } \\
\left.\text { (Ton } / \mathrm{m}^{3} / \mathrm{kWh}\right)\end{array}$ \\
\hline $\begin{array}{c}\text { Kömür } \\
\text { (evsel) }\end{array}$ & 45.775 & $124.925,00$ \\
Doğalgaz & 48.040 & $7.691 .048,56$ \\
Elektrik & & $884.202 .303,00$ \\
\hline
\end{tabular}

Karbon ayak izi belirlenmesinde ikinci sırada yer alan ulaşım kaleminde kullanılacak olan motorlu taşıt sayıları Tablo 4'te verilmiştir [28]. Tablolar halinde verilen tüm bu değerler Türkiye İstatistik Kurumunun Ocak 2021 tarihinde yayınlamıș olduğu raporlardan elde edilmiștir.

Tablo 4. Türkiye ve Burdur ili için motorlu kara taşıtları sayısı

\begin{tabular}{ccc}
\hline Taşıt Türü & Türkiye & Burdur \\
\hline Otomobil & 13.172 .111 & 55.775 \\
Minibüs & 492.972 & 1.376 \\
Otobüs & 212.335 & 824 \\
Kamyonet & 3.961 .475 & 16.220 \\
Kamyon & 862.484 & 5.769 \\
Motosiklet & 3.520 .562 & 35.095 \\
Özel Amaçlı & 71.174 & 391 \\
Traktör & 1.963 .628 & 23.079 \\
Toplam & 24.256 .741 & 138.529 \\
\hline
\end{tabular}

Karbon ayak izi belirlenmesinde ikinci sırada yer alan ulaşım kaleminde kullanılacak olan otomobillerin yakıt cinsine göre dağılımının 2020 yılı değerleri Tablo 5'te verilmiștir [35].

Tablo 5. Trafiğe kayıtlı otomobillerin yakıt cinsine göre dağılımı

\begin{tabular}{ccc}
\hline Yakıt Türü & Adet & Oran (\%) \\
\hline Benzin & 3.201 .894 & 24,4 \\
Dizel & 5.014 .356 & 38,3 \\
LPG & 4.810 .018 & 36,7 \\
Elektrikli - & 36.487 & 0,3 \\
Hibrit & 36.286 & 0,3 \\
Bilinmeyen & 13.099 .041 & \\
Toplam &
\end{tabular}

Karbon ayak izi belirlenmesinde ikinci sırada yer alan ulaşım kaleminde kullanılacak olan motorlu taşıtların ortalama yakıt tüketimlerine ait veriler Tablo 6'da verilmiștir. Literatürde bulunan çalışmadan alınan verilere göre, traktörlerin yıllık kullanım süreleri ortalamasının 443 saat olduğu belirlenmiştir [29]. Traktörler ve iş makinalarında $\mathrm{km}$ veya saatlik kesin bir yakıt tüketim değeri vermek mümkün değildir. Çalışma koşulları ve yapılan işlemlerde kullanılan motor gücünde değişiklikleri hesaplamak veya tahmin etmek çok zordur. Bu çalışmada traktör için saatlik ortalama yakıt tüketim değeri, literatürde bulunan çalışmaların doğrultusunda $7,5 \mathrm{~L} / \mathrm{h}$ olarak kabul edilmiştir [30]. Özel amaçlı araçların yıllık ortalama $8.000 \mathrm{~km}$ yaptığı ve bir kamyonet kadar yakıt tüketimine sahip olduğu kabulü yapılmıştır.

Tablo 6. Taşıt cinsine göre yıl-kilometre, yakıt tüketimi istatistikleri [15,28,31]

\begin{tabular}{cccc}
\hline & $\begin{array}{c}\text { Ortalama } \\
(\mathrm{km} / \mathrm{yl})\end{array}$ & $\begin{array}{c}\text { Yakıt } \\
\text { Tüketimi } \\
(\mathrm{L} / 100 \mathrm{~km})\end{array}$ & $\begin{array}{c}\text { Şehir içi } \\
\text { Kullanım } \\
\text { Oranları }\end{array}$ \\
\hline Otomobil & 13.776 & $\begin{array}{c}\text { Benzin 8,5 } \\
\text { Motorin 7,3 } \\
\text { LPG 11,2 }\end{array}$ & 0,7 \\
Minibüs & 27.077 & 10,9 & 1,0 \\
Otobüs & 48.826 & 27,0 & 1,0 \\
Kamyonet & 16.871 & 10,9 & 0,5 \\
Kamyon & 42.791 & 29,9 & 0,2 \\
Motosiklet & 3.960 & 4,0 & 1,0 \\
\hline
\end{tabular}

Evsel atıklar; kısaca evlerden atılan, tehlikeli ve zararlı atık kavramına girmeyen; mutfak, bahçe gibi yerlerden gelen katı atıklar olarak tanımlanabilir. Evsel katı atıkların çoğunluğunu organik atıklar, kalan kısmını ise kâğıt, karton, tekstil, plastik, deri, ağaç, metal, cam ve kül gibi maddeler oluşturur.

Burdur İli, Merkez İlçesi, Necatibey Mahallesinde Burdur Belediyeler Birliğine ait Katı Atık Düzenli Depolama Tesisi bulunmaktadır. Düzenli depolama alanına Merkez ilçeden günlük 140,8 ton yllık olarak 51.392 ton katı atık gelmektedir. Burdur ili Merkez ilçede günlük kişi başı 1,26 kg katı atık üretilmektedir.

İlçelerde mevcut durumda vahşi depolama yapılmaktadır. Çeltikçi, Karamanlı ve Gölhisar ilçelerinde inşaat, izin ve lisans süreci devam eden aktarma istasyonlarının tamamlanması halinde Merkez ilçeye aktarılacak katı atık tonajı ortalama 250 ton/gün'e çıkması 


\section{DEÜ FMD 24(70), 317-327, 2022}

öngörülmektedir. İlçelerdeki yapımı devam eden Aktarma istasyonları aktif hale geldiğinde bütün ilçelerin atıkları düzenli depolama alanına getirilecek ve vahşi depolama alanları rehabilite edilecektir.

$\mathrm{Bu}$ çalıșmada, Burdur ilinde bulunan ağaçların tahmini yapılarak $\mathrm{CO}_{2}$ emilimine katkısı eklenmiştir. $6.887 \mathrm{~km}^{2}$ yüzölçümü ne sahip Burdur ili, $783.562 \quad \mathrm{~km}^{2 \prime l}$ lik Türkiye yüzölçümünün \%0,87 'sini kaplamaktadır. Burdur ili orman alanları 3 farklı bölge altında toplanmaktadır. Birinci bölge, Burdur/Merkez, Ağlasun, Çamoluk, Yeşilova, ikinci bölge Gölhisar, Gölova, Dirmil, İbecik, Tefenni ve üçüncü bölge ise Bucak, Melli, Pamucak, Çamlık, Uğurlu, Kestel alanlarını kapsamaktadır. Burdur ili orman bölgelerine ait toplam, normal ve bozuk ormanlara ait alanlar Tablo 7'de verilmiştir. Ormanlık alanlar içindeki ağaç türlerinin oransal dağılımı ise Kızılçam (\%31,91) Anadolu karaçamı $(\% 28,65)$, Meșe türleri $(\% 22,07)$, Ardıç türleri $(\% 14,04)$ ve diğer ağaçlar $(\% 3,33)$ olarak bildirilmiștir [32].

Tablo 7. Burdur İli orman bölgelerine ait veriler

\begin{tabular}{lccc}
\hline $\begin{array}{c}\text { Orman } \\
\text { Bölgesi }\end{array}$ & $\begin{array}{c}\text { Normal } \\
\text { Orman } \\
\text { Alan (Ha) }\end{array}$ & $\begin{array}{c}\text { Bozuk } \\
\text { Orman } \\
\text { Alan (Ha) }\end{array}$ & $\begin{array}{c}\text { Toplam } \\
\text { Orman } \\
\text { Alan (Ha) }\end{array}$ \\
\hline Birinci & 54.367 & 84.498 & 138.865 \\
İkinci & 55.515 & 32.659 & 88.175 \\
Üçüncü & 54.794 & 42.483 & 97.277 \\
Toplam & 164.676 & 159.641 & 324.317 \\
\hline
\end{tabular}

Carus vd. Burdur-Ağlasun yöresinde doğal, aynı yaşlı, saf ve müdahale görmemiş kızılçam meșcerelerinde ağaç sayının belirlenmesinde yedi ağaç örnek nokta yöntemini kullanmıșlardır. Bölgede yaklașık 50 yașında ağaçların bulunduğu 25 noktadan verileri elde etmişler. $\mathrm{Bu}$ elde edilen verileri farklı istatistiksel dağılımlar ve alan regresyon modelleri ile analiz etmişler. Örnek alınan bölgedeki bir ağacı merkez olarak belirleyip ona en yakın konumdaki altı ağaç ve bu ağaçların yerleşim mesafeleri kullanılarak yapılan ağaç sayısı hesabında $780 \mathrm{ad} /$ ha kızılçam olduğunu tespit etmişlerdir [33]. Bölgedeki kızlçam ormanları toplam alan içinde \%31,91 lik bir alanı kapsamaktadır. Bu çalıșmada Burdur ili ağaç sayısının belirlenmesinde ağaç türlerinin dağılımı, tüm alanlardaki ağaç yașının aynı olmayışı gibi faktörler de dikkate alınmıştır. Tarafimızca yapılan oransal hesaplama sonucunda toplam ağaç sayısının 46.596 .890 olduğu kabulü yapılmıştır.
Belirli bir faaliyet için sera gazı emisyonlarının hesaplanmasinda, öncelikle faaliyet olușumundaki aktivite veriler toplanır. Daha sonra bu veriler uluslararası kuruluşlar tarafından hazırlanan sera gazı dönüșüm faktörleri tablosunda ilgili dönüşüm faktörü ile çarpılır. Elde edilen sonuç bize ilgili faaliyet için tahmini sera gazı emisyon miktarını verir. Tüm kapsamlar içinde yer alan sera gazı emisyonları (SGE), eşitlik 1'de bulunan faaliyet verileri (FV) ve emisyon dönüșüm faktörü (EDF) ile hesaplanmaktadır.

$\mathrm{SGE}=\mathrm{FVxEDF}$

Sera gazı (greenhouse gas, GHG) emisyonlarının belirlenmesi için Birleşik Krallık Hükümeti Enerji ve İklim Değişikliği Başkanlığı (Department of Energy \& Climate Change, DECC) ile Çevre, Gıda ve Köy İşleri Bakanlığı (Department for Environment, Food \& Rural Affairs, DEFRA) tarafindan hazırlanan ve uluslararası platformlarda kabul görmüş dönüşüm faktörleri kullanılmaktadır. $\mathrm{Bu}$ çalışmadaki hesaplamalar için gerekli dönüşüm faktörleri Tablo 8'de verilmiștir [15,28,34].

Tablo 8. Emisyon hesaplarında kullanılan dönüșüm faktörleri

\begin{tabular}{ccc}
\hline Bileşen & Birimi & $\begin{array}{c}\text { Dönüşüm } \\
\text { Faktörü }\end{array}$ \\
\hline Karayolu & $\mathrm{tCO}_{2} / 10^{3} \mathrm{~L}$ benzin & 2,302 \\
Araçları & $\mathrm{tCO}_{2} / 10^{3} \mathrm{~L}$ dizel & 2,676 \\
& $\mathrm{tCO}_{2} / 10^{3} \mathrm{~L} \mathrm{LPG}$ & 1,505 \\
Kömür yakıtı & $\mathrm{tCO}_{2} / \mathrm{t} \mathrm{kömür}^{2,856}$ \\
Doğalgaz & $\mathrm{tCO}_{2} / \mathrm{m}^{3}$ & $2,028 \times 10^{-3}$ \\
Elektrik & $\mathrm{tCO}_{2} / \mathrm{kWh}_{\mathrm{e}}$ & $4,12 \times 10^{-4}$ \\
Katı atı & $\mathrm{tCO}_{2} / \mathrm{t}$ atı & 0,19 \\
\hline
\end{tabular}

Birleșik Krallık Hükümeti Dönüşüm Faktörleri kullanılarak Sera gazı (GHG) raporlaması ve karbon ayak izinin belirlenmesi üç farklı (Kapsam 1,2,3) kategoride değerlendirilmektedir. Kapsam 1 (doğrudan emisyonlar), bölgedeki kontrol edilebilen faaliyetlerin (yakıt tüketimi vb.) sonucu oluşan doğrudan gaz salınımlarını; Kapsam 2 (dolaylı enerji), bölge dişında üretimi yapılan ve satın alınarak kullanılan elektrik, isı, buhar ve soğutma gibi enerjilerin bölgede tüketilmesinden kaynaklanan dolaylı salınımları; Kapsam 3 (diğer dolaylı) ise kontrol etmediğiniz ve Kapsam 2 emisyonları olarak sinıflandırılmayan kaynaklardan meydana gelen gaz salınımlarıdır. 


\section{DEÜ FMD 24(70), 317-327, 2022}

Bu sınıflandırmaya örnek olmak üzere, Kapsam 1'de barınma yerlerinde ısınma amaçlı yakıt tüketimi (kömür, doğalgaz vb.) ve ulaşım ve nakliye amaçlı taşıtların yakıt tüketimi (Benzin, Dizel, LPG) kaynaklı gaz salınımlarıdır. Kapsam 2 'de konut, sanayi, ticarethane, resmi kurumlar, aydınlatma ve tarımsal sulama gibi alanlarda kullanılan elektrik tüketimi kaynaklı gaz salınımlarıdır. Kapsam 3'te ise bölge sınırları içinde bertaraf edilen çalışma bölgesi yașayanları tarafından olușan katı atıklar kaynaklı gaz salınımlarıdır. Kapsam 1, 2 ve 3 dahilinde incelenecek olan emisyon kaynaklarının gruplandırması Tablo 9'da görülmektedir.

Tablo 9. Emisyon kaynağına göre kapsam siniflandırması

\begin{tabular}{ll}
\hline Kapsam & Emisyon Kaynağı \\
\hline Kapsam 1 & Kömür Tüketimi \\
Konut & $\begin{array}{l}\text { Doğalgaz Tüketimi } \\
\text { Doğalgaz Tüketimi } \\
\text { Benzin Tüketimi }\end{array}$ \\
Ulaşım & Dizel Tüketimi \\
& LPG Tüketimi \\
Kapsam 2 & \\
Konut & Elektrik Tüketimi \\
Sanayi & Elektrik Tüketimi \\
Ticarethane ve kurumlar & Elektrik Tüketimi \\
Aydınlatma & Elektrik Tüketimi \\
Tarımsal sulama & Elektrik Tüketimi \\
Kapsam 3 & \\
Konut & Atık Oluşumu \\
\hline
\end{tabular}

\section{Bulgular}

$\mathrm{Bu}$ çalışmada ele alınan emisyon kaynakları kapsam 1, kapsam 2 ve kapsam 3 olarak ayr ayrı incelenmiştir. Her bir kapsam kendi içerisinde de detaylandırılarak açıklamaları gerçekleștirilmiştir. Kapsam 1, kapsam 2 ve kapsam 3 ile yıllık üretilen $\mathrm{CO}_{2}$ miktarının bin ton/yll birimi ile Sekil 2'de bulunan grafikte verilmiştir. Tüm kapsamlar toplamında 1.097.599,90 ton/yıl $\mathrm{CO}_{2}$ salınımı gerçekleştiği görülmektedir. 2018 yılı sonunda kiși bașına karbon salınımı ABD'de 16,6 ton, Çin'de 7 ton, Avrupa Birliği'nde 6,7 ton olarak gerçekleşmiştir. Türkiye'de kişi başına karbon salınımı ise 5,2 ton oldu. Burdur ili için bu rakam kişi bașı 4,1 ton olarak tespit edilmiștir.

Kapsam 1'de 723,537 bin ton/yll $\mathrm{CO}_{2}$, kapsam 2'de 364,29 bin ton/yll $\mathrm{CO}_{2}$ ve kapsam 3'te ise 9,76 bin ton/yll $\mathrm{CO}_{2}$ salınımı gerçekleștiği sonucu elde edilmiștir. Bu çalıșmada ele alınan
$\mathrm{CO}_{2}$ salınımlarının, \%65,92 oranında kapsam 1 , $\% 33,19$ oranında kapsam 2 ve \%0,89 oranında kapsam 3 bazlı meydana geldiği saptanmıștır. En az $\mathrm{CO}_{2}$ salınımı kapsam 3 bazlı oluştuğu görülmektedir. Bunun nedenlerinden birisi atık toplama sürecinin sadece merkez ilçede gerçekleştirilmesidir. İlçelerde süreci devam eden atık toplama merkezlerinin devreye alınması ile bu oranın artması düșünülmektedir.

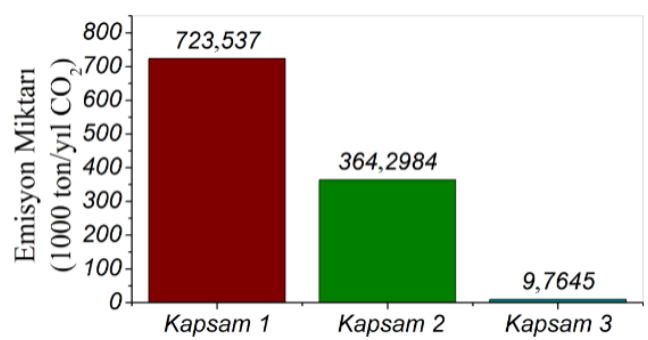

Şekil 2. Kapsam 1, 2 ve 3'e ait $\mathrm{CO}_{2}$ salınımı (1000 ton/yll) değerleri

Kapsam 1 çerçevesinde, konut, serbest tüketici ve ulaşımdan kaynaklı meydana gelen $\mathrm{CO}_{2}$ emisyon miktarları ele alınmış olup Şekil 3'te verilmiștir. Konutlardan kaynakl 420,654 bin, serbest tüketici 68,419 bin ve ulaşık kaynaklı ise 234,463 bin ton $\mathrm{CO}_{2}$ salınımı gerçekleșmiștir. Kapsam 1'de gerçekleșen $\mathrm{CO}_{2}$ salınımının \%58,14'ü konut, \%32,41'ü ulaşım, $\% 9,46$ 'ü serbest tüketiciler tarafından gerçekleştirilmiştir. Kapsam 1 çerçevesinde en yüksek $\mathrm{CO}_{2}$ salınımı konutlar, ikinci yüksek salınımı ise ulaşım kategorisinin gerçekleştirdiği görülmektedir.

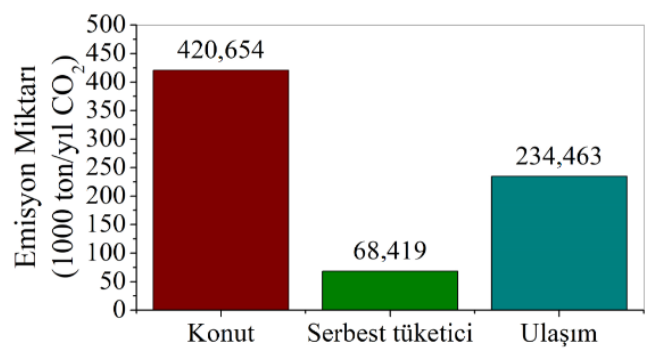

Şekil 3. Kapsam 1 ile salınımı yapılan $\mathrm{CO}_{2}$ miktarları

Konutlardan gerçekleşen salınımın yüksek olmasının en temel nedeninin kömür kullanımı olduğu Şekil 4'te de açıkça görülmektedir. Burdur ilinde toplam hane sayısı 93.815, doğal gaz kullanılan hane sayısı 48.040 ve kömür kullanan hane sayısı ise 45.775 olarak belirlenmiştir. Kömür kullanan hane oranı 


\section{DEÜ FMD 24(70), 317-327, 2022}

\%48,79 olmasına karșın, konut bazlı $\mathrm{CO}_{2}$ salınımının \%77,7'ünü meydana getirdiği sonucu elde edilmiştir. $\mathrm{CO}_{2}$ salınımının azaltılması için konutlarda doğal gaz kullanımına geçişin önemli bir kriter olduğu düşünülmektedir.

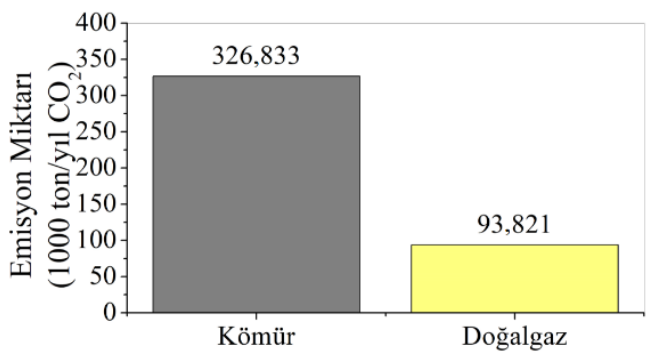

Şekil 4. Kapsam 1, konutlar ile yapılan $\mathrm{CO}_{2}$ salınımı değerleri

Ulaşım bazlı meydana gelen $\mathrm{CO}_{2}$ salınımları, benzin, dizel, LPG ve elektrik olarak 4 kategoride incelenmiş olup elde emisyon miktarlarını içeren grafik Șekil 5'te verilmiștir. Dizel yakıt tüketimi otomobil, minibüs, otobüs, kamyonet, kamyon, traktör ve özel amaçlı araçlar tarafından gerçekleștirilmektedir. Benzin yakıt tüketimi, otomobil ve motosiklet tarafından gerçekleșmektedir. Ulașımda \%69,33'lük oranla en çok emisyon salınımı dizel araçlar tarafından gerçekleştiği görülmüştür.

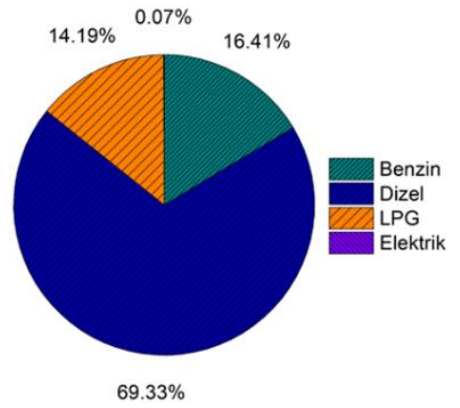

Şekil 5. Ulaşım bazlı yapılan $\mathrm{CO}_{2}$ salınımları

Ulașım bazlı meydana gelen $\mathrm{CO}_{2}$ salınımı oranları, otomobil, minibüs, otobüs, kamyon, kamyonet, traktör, motosiklet ve özel amaçlı araçlar olmak üzere 8 kategoride incelenmiştir. Ulaşım bazlı meydana gelen emisyon miktarı, 234,463, otomobil için 99,352, kamyon için 39,503, kamyonet için 39,909 ve minibüs için 10,867 bin ton / yll $\mathrm{CO}_{2}$ olarak hesaplanmıștır. Taşıt cinsine bağlı, ulaşım bazlı meydana gelen $\mathrm{CO}_{2}$ salınımı oranları Sekil 6'da verilmiștir. En yüksek $\mathrm{CO}_{2}$ salınımını gerçekleștiren tașıt cinsi \%42,37'lik oran ile otomobil olduğu görülmüştür. Toplam otomobil sayısının $\% 24,4$ 'ünü benzinli, \%38,3'ünü dizel, \%36,7'sini LPG ve \%3'lük kısmını elektrikli otomobiller olușturmaktadır. Bunların gerçekleștirmiș olduğu $\mathrm{CO}_{2}$ emisyon oranları ise benzinlide $\% 25,84$, dizelde $\% 40,5$, LPG'de $\% 33$,48 ve elektriklide \%0,161 olarak belirlenmiștir. $\mathrm{CO}_{2}$ salınımı bakımından değerlendirdiğinde sırasıyla, elektrikli, LPG'li, benzinli ve dizel araçların kullanımı daha avantajlı olduğu görülmektedir.

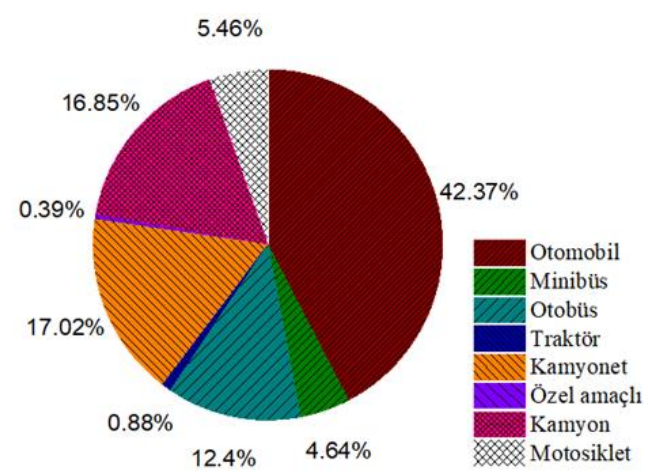

Şekil 6. Taşıt bazlı yapılan $\mathrm{CO}_{2}$ salınımları

Kapsam 2 bazlı $\mathrm{CO}_{2}$ salınımının tamamı elektrik tüketimine bağlı olarak gerçekleștirilmiştir. Atmosfere kapsam 2 bazlı salınımı gerçekleşen $\mathrm{CO}_{2}$ emisyonunun konut, sanayi, ticarethane ve kurumlar, aydınlatma ve tarımsal sulama olarak siniflandırılması durumunda belirlenen değerler Şekil 7'de bulunan grafikte yer almaktadır. $\mathrm{Bu}$ kapsamda konutları 75,57, sanayinin 182,45 , ticarethane ve kurumlarin 82,283 , aydınlatmanın 17,12 ve tarımsal sulamanın 6,28 bin ton/yll $\mathrm{CO}_{2}$ emisyonu salınımı gerçekleştirdiği görülmektedir. Kapsam 2 bazlı $\mathrm{CO}_{2}$ salınımının en çok gerçekleştiği bölüm sanayi olurken, en az salınım tarımsal sulama ile gerçekleștiği görülmektedir.

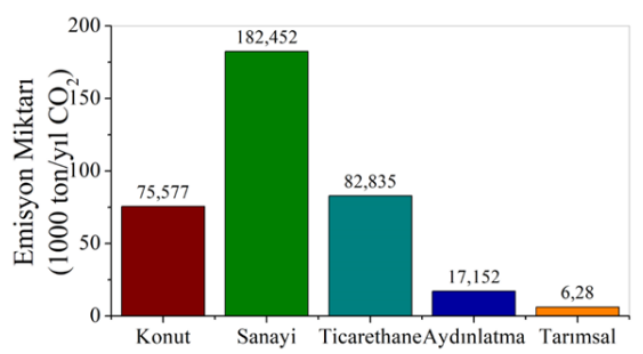

Şekil 7. Kapsam 2 bazlı $\mathrm{CO}_{2}$ salınımı (bin ton/yll) değerleri 
Ağaç bașına yılda $12 \quad \mathrm{~kg} \quad \mathrm{CO}_{2} \quad$ emilimi gerçekleştiği kabulü literatürde yer almaktadır $[15,16]$. Toplam ağaç sayısı 46.596 .890 adet olduğu yazarlar tarafından hesaplanmıştır. Burdur ilinde bulunan mevcut ağaçların tahmini $\mathrm{CO}_{2}$ emilimi, 559.162,69 ton/yll olarak belirlenmiștir. Bozuk orman alanlarının ağaçlandırılması durumunda $\mathrm{CO}_{2}$ emilimine $542.064,55$ ton/yıl pozitif katkı sağlaması söz konusudur.

\section{Tartışma ve Sonuç}

Burdur ili karbon ayak izi belirlenmesinde birincil (doğrudan) ayak izinin belirlenmesi için barınma, ulașım ve katı atıklardan olușan karbon salınımı, dönüşüm faktörleri kullanılarak hesaplanmıştır. Toplam 1.097.599,90 $\mathrm{tCO}_{2}$ salınımı olduğu tespit edilmiştir. Burdur ili için kişi başı $\mathrm{CO}_{2}$ salınımı 3,62 ton/yll olarak belirlenmiş olup Türkiye ortalamasının altında olduğu görülmüştür. Burdur ili sınırlarında dikili ağaç sayısının karbon salınımına yapmıș olduğu olumlu etkilerde hesaplamaya dahil edildiğinde net salınım miktarı 538.437,21 $\mathrm{tCO}_{2}$ olarak belirlenmiștir. Bozuk orman alanlarının ağaçlandırılması ile 542.064,55 ton/yı $\mathrm{CO}_{2}$ emilimi gerçekleștirileceği belirlenmiştir. Bozuk orman alanlarının ağaçlandırılması durumunda $\mathrm{CO}_{2}$ salınım değerinin yaklaşık olarak sıfırlanabileceği hesaplanmıştır.

Tüm dünyanın üzerinde yoğunlaștığı karbon salınımını azaltmaya yönelik çalışmalar göz önüne alındığında, bu azaltma çalışmalarının bir zorunluluk halini aldığı görülmektedir. Burdur ili birincil karbon ayak izi bakımından dünya ve Türkiye ortalamasının altında olmasına rağmen, karbon nötr bölge olması için kısa vadede ve orta vadede yapılacak eylemlere dair bir plan hazırlamalıdır. $\mathrm{Bu}$ kapsamda ısınma için kullanılan kömür yerine doğalgaz kullanımınının teşvik edilmesi, fosil yakıtlı araçlar yerine elektrikli ve hibrit araçların kullanımınının sağlanması önerilmektedir. Bunun yanında bireysel taşıt kullanımı yerine, toplu taşımanın tercih edilmesi de $\mathrm{CO}_{2}$ salınımında önemli oranda iyileșme sağlayacağı düșünülmektedir. Burdur ili merkezinde bulunan $7 \mathrm{~km}$ uzunluğa sahip bisiklet yolu genişletilmeli ve bisiklet kullanımı teşvik edilmelidir. Karbon ayak izinin düşürülmesinde kullanılacak bir diğer yöntem ise salınımı gerçekleştirilen $\mathrm{CO}_{2}$ gazlarının emilimini arttırmaktır. Bu gazların emilimini sağlayacak ağaçlandırmanın da genişletilmesi önerilmektedir.

\section{Kaynakça}

[1] Mızık, E., Yiğit Avdan, Z. 2020. Sürdürülebilirliğin Temel Taşı: Ekolojik Ayak İzi. Doğal Afetler ve Çevre Dergisi, 6(2): 451467. Doi: $10.21324 /$ dacd.630825

[2] Lin D, Hanscom L, Murthy A, Galli A, Evans M, Neill E, Mancini MS, Martindill J, Medouar F-Z, Huang S, Wackernagel M. 2018. Ecological Footprint Accounting for Countries: Updates and Results of the National Footprint Accounts, 2012-2018. Resources, 7(3):58. https://doi.org/10.3390/resources7030058

[3] WWF. 2012. Türkiye'nin Ekolojik Ayak İzi Raporu,

https://www.wwf.org.tr/yayinlarimiz/raporl arimiz/?1412/, Son Erişim Tarihi: 17.04.2021

[4] Isman, M., Archambault, M., Racette, P., Konga, C. N., Llaque, R. M., Lin, D., OuelletPlamondon, C. M. 2018. Ecological Footprint assessment for targeting climate change mitigation in cities: A case study of 15 Canadian cities according to census metropolitan areas. Journal of cleaner production, 174, 1032-1043. https://doi.org/10.1016/j.jclepro.2017.10.18 9

[5] Mancini, M. S., Galli, A., Niccolucci, V., Lin, D., Bastianoni, S., Wackernagel, M., Marchettini, N. 2016. Ecological footprint: refining the carbon footprint calculation. Ecological indicators, 61, 390-403. https://doi.org/10.1016/j.ecolind.2015.09.0 40

[6] Fakher, H. A. 2019. Investigating the determinant factors of environmental quality (based on ecological carbon footprint index). Environmental Science and Pollution Research, 26(10), 10276-10291. https://doi.org/10.1007/s11356-01904452-3

[7] Bello, M. O., Solarin, S. A., Yen, Y. Y. 2018. The impact of electricity consumption on $\mathrm{CO} 2$ emission, carbon footprint, water footprint and ecological footprint: the role of hydropower in an emerging economy. Journal of environmental management, 219, 218-230. https://doi.org/10.1016/j.jenvman.2018.04. 101 
[8] Erden Özsoy, C. 2015. Düşük Karbon Ekonomisi Ve Türkiye'nin Karbon Ayak İzi. Hak İș Uluslararası Emek ve Toplum Dergisi, $4(9)$, 198-215. https://dergipark.org.tr/tr/pub/hakisderg/i ssue/7583/99549

[9] Solarin, S. A. 2019. Convergence in CO2 emissions, carbon footprint and ecological footprint: evidence from OECD countries. Environmental Science and Pollution Research, 26(6), 6167-6181. https://doi.org/10.1007/s11356-018-39938

[10] Chen, J., Fan, W., Li, D., Liu, X., \& Song, M. 2020. Driving factors of global carbon footprint pressure: Based on vegetation carbon sequestration. Applied Energy, 267, 114914

https://doi.org/10.1016/j.apenergy.2020.11 4914

[11] Wang, S., Chen, B. 2018. Three-Tier carbon accounting model for cities. Applied Energy, 229, 163-175. https://doi.org/10.1016/j.apenergy.2018.07. 109

[12] Özgen, I., Binboğa, G., Güneş, S. T. 2021. An assessment of the carbon footprint of restaurants based on energy consumption: A case study of a local pizza chain in Turkey. Journal of Foodservice Business Research, 121.

https://doi.org/10.1080/15378020.2021.18 89910

[13] Schueler, M., Hansen, S., Paulsen, H. M. 2018. Discrimination of milk carbon footprints from different dairy farms when using IPCC Tier 1 methodology for calculation of GHG emissions from managed soils. Journal of Cleaner Production, 177, 899-907. https://doi.org/10.1016/j.jclepro.2017.12.22 7

[14] Sununta, N., Sedpho, S., Sampattagul, S. 2018. City carbon footprint evaluation and forecasting case study: dan sai municipality. Chemical Engineering Transactions, 63, 277 282. http://dx.doi.org/10.3303/CET1863047

[15] Argun, M. E., Ergüç, R., Yunus, Sarı. 2019. Konya/Selçuklu ilçesi karbon ayak izinin belirlenmesi. Selçuk Üniversitesi Mühendislik, Bilim ve Teknoloji Dergisi, 7(2), 287-297. Doi: 10.15317/Scitech.2019.199

[16] Kocaman, A. 2020. Sanayi Şehri Karabük İlindeki Fosil Yakıt Kaynaklı Karbon Ayak İzinin Belirlenmesi ve Orman Varlıklarının
Emisyonu Azaltmadaki Etkisi. İzlek Akademik Dergi, (3), 44-55.

[17] Kumaş, K., Akyüz, A. Ö., Zaman, M., Güngör, A. 2019. Sürdürülebilir Bir Çevre İçin Karbon Ayak izi Tespiti: MAKÜ Bucak Sağlık Yüksekokulu Örneği. El-Cezeri Journal of Science and Engineering, 6(1), 108-117. https://doi.org/10.31202/ecjse.459478

[18] Kumaş, K., Onur, İnan, Akyüz, A. Ö., Güngör, A. 2019. Muğla Dalaman Havalimanı Uçaklardan Kaynaklanan Karbon Ayak İzinin Belirlenmesi. Akademik Platform Mühendislik ve Fen Bilimleri Dergisi, 7(2), 291-297. https://doi.org/10.21541/apjes.466338

[19] Civelekoğlu, G., Bıyık, Y. 2020. Isparta İlinde Karayolu Kaynaklı Karbon Ayak İzinin Hesaplanması. Bilge International Journal of Science and Technology Research, 4(2), 7887.

[20] Kaplan, A., Örücü, Ö. K. 2019. Burdur Gölü ve Çevresinin Peyzaj Değerleri Açısından Turizm Potansiyelinin Belirlenmesi. Mimarlık Bilimleri ve Uygulamaları Dergisi, 4(2), 105121. https://doi.org/10.30785/mbud.555622

[21] TÜIKK. 2021. Adrese Dayalı Nüfus Kayıt Sistemi Sonuçları, Ocak 2021.

[22] EPDK. 2021. T.C. Enerji Piyasası Düzenleme Kurumu, 2020 yılı Doğalgaz piyasası sektör raporu.

[23] GAZBİR. Türkiye Doğalgaz Dağıtıcıları Birliği, 2020 yılı Doğalgaz dağıtım sektör raporu.

[24] TEDAȘ, CK Akdeniz, https://www.ckakdeniz.com.tr/, Son Erișim Tarihi: 17.04.2021

[25] EPDK. 2021. T.C. Enerji Piyasası Düzenleme Kurumu, Elektrik Piyasası Sektör Raporu, Ocak 2021. https://www.epdk.gov.tr/Detay/DownloadD ocument?id=aUa1d3URIMU=, Son Erişim Tarihi: 17.04.2021

[26] Gürsoy Haksevenler, B., Çelik Onat, G., Akpınar, B., Bedel, T. 2020. Yerel Yönetimler İçin Karbon Ayak İzinin Belirlenmesi: Ümraniye Belediyesi Örneği. Doğal Afetler ve Çevre Dergisi, 6(2): 319-333. DOI: 10.21324/dacd.639370.

[27] DEFRA. 2016. Greenhouse gas reporting Conversion factors 2016, https://www.gov.uk/government/publicatio ns/greenhouse-gas-reporting-conversionfactors-2016, Son Erișim Tarihi: 17.04.2021 
[28] TÜİK. 2020. Taşıt-kilometre İstatistikleri, 2018. Türkiye İstatistik Kurumu Haber Bülteni, Sayı:33627 Yayın tarihi: 21 Mayıs 2020.

[29] Ali, Berk, Keskin, A. H. 2020. Tarım İşletmelerinde Traktör Kullanım Durumu ve Marka Tercihleri; Konya İli Çumra İlçesi Örneği. Ziraat Mühendisliği, (370), 4-17, https://doi.org/10.33724/zm.710528.

[30] Sümer, S., Sabancl, A., Ülker, K. "Tarım Traktörlergnde, Güç Ve Yüklenme Koşullarına Bağlı Olarak, Özgül Yakıt Tüketimi Ve Egzoz Gazı Sıcaklığı Arası İlişkilerin İncelenmesi Üzerine Bir Araştırma"

[31] Atabey, T. 2013. Karbon ayak izinin hesaplanması: Diyarbakır örneği. Fırat Üniversitesi Yüksek Lisans Tezi, Elazığ.

[32] Carus, S., Catal, Y. 2012. Burdur Yöresi Orman İşletmeciliğinin Temel Özellikleri, Sorunları ve Çözüm Önerileri. Mehmet Akif Ersoy Üniversitesi Fen Bilimleri Enstitüsü Dergisi, 3(1): $\quad$ 53-59. https://dergipark.org.tr/tr/pub/makufebed/ issue $/ 19422 / 206556$

[33] Carus, S., Çatal, Y. 2008. Kızılçam (Pinus brutia Ten.) Meșcerelerinde 7-Ağaç Örnek Nokta Yöntemiyle Meşcere Ağaç Sayısının Çap Basamaklarına Dağılımının Belirlenmesi. Süleyman Demirel Üniversitesi Orman Fakültesi Dergisi, 2: 158-169.

[34] IPCC. 2019. Intergovernmental Panel on Climate Change (IPCC) report. 24 September 2019.

[35] TÜíK, Trafiğe kayıtlı otomobillerin yakıt cinsine göre dağılımı, $2004-2021$. 